\title{
Report of a Case of Signet Ring Carcinoma Presenting as Gastric Mucosal Thickening: A Diagnostic Dilemma
}

\section{Farklı Tanı Yöntemlerine Rağmen Teşhis Konulamayan Taşlı Yüzük Hücreli Karsinom- Olgu Sunumu}

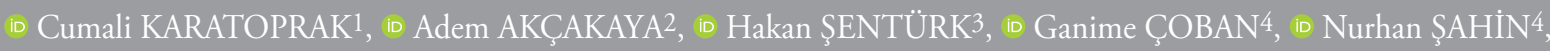

(i) Hacı Mehmet TÜRK5

'Bezmialem Vakıf University, Faculty of Medicine, Department of Internal Medicine, İstanbul, Turkey

${ }^{2}$ Bezmialem Vakıf University Faculty of Medicine, Department of General Surgery Clinic, İstanbul, Turkey

${ }_{3}^{3 B e z m i a l e m ~ V a k ı f ~ U n i v e r s i t y ~ F a c u l t y ~ o f ~ M e d i c i n e, ~ D e p a r t m e n t ~ o f ~ I n t e r n a l ~ M e d i c i n e ~ C l i n i c, ~ G a s t r o e n t e r o l o g y ~ D e p a r t m e n t, ~ I ̇ s t a n b u l, ~ T u r k e y ~}$

${ }^{4}$ Bezmialem Vakif University Faculty of Medicine, Department of Pathology Clinic, İstanbul, Turkey

${ }^{5}$ Bezmialem Vakif University Faculty of Medicine, Department of Internal Medicine Clinic, Oncology Department, İstanbul, Turkey

\section{ABSTRACT}

The number of cancer cases has been increasing worldwide. Early diagnosis and tumor resection remain as the most effective treatments for gastric cancer. However, early diagnosis is not always possible as it is frequently not possible to make treatment decisions without pathologic diagnosis in patients with clinically suspected cancer. This causes delays in diagnosing cancer. We presented a 58 years old woman with gastric signet ring cell carcinoma that could not be diagnosed despite using four different methods of stomach biopsies. We aimed to emphasize that despite the use of advanced methods, if clinical cancer in non-diagnosed cases is suspected, we should be more aggressive for early diagnosis.

Keywords: Gastric mucosal thickening, diagnostic dilemmas, signet ring cell carcinoma

\section{ÖZ}

Kanser olgularının sayısı dünya çapında artmaktadır. Erken tanı ve tümör rezeksiyonu, mide kanseri için hala en etkili tedavi olarak kabul edilmektedir. Ancak erken tanı koymak her zaman mümkün değildir. Klinik olarak kanser şüphesi olan hastalarda patolojik tanı olmaksızın tedavi kararı vermek çoğu zaman mümkün değildir. Bu durum kanser teşhisinde gecikmelere neden olur. Dört farklı yöntem ile mide biyopsi yapılmasına rağmen tanı konulamayan 58 yaşında mide taşl yüzük hücreli karsinom olgusunu sunduk. İleri yöntemler kullanılmasına rağmen, tanı konulamayan olgularda klinik kanser şüphesi varsa erken teşhis için daha agresif davranmamız gerektiğini vurgulamak ve çelişkilere dikkat çekmek istedik.

Anahtar Sözcükler: Gastrik mukozal kalınlaşma, tanı zorlukları, taşlı yüzük hücreli karsinom

\section{Introduction}

The number of patients diagnosed with early-stage gastric cancer increases with technology development, increasing access to medical system and level of consciousness in people (1). Highdefinition endoscopic technology and various sampling and histological processing methods are primary in the early diagnosis of cancer (2). However, challenging cases remain, and such cases lead to difficulties and uncertainty in the clinician's approach to diagnosis and treatment (3). Repeated biopsies and follow-ups to achieve diagnosis may reduce the chance of early treatment for these patients. We aimed to present a case with an increased thickness in the stomach wall wherein a definitive diagnosis could

Address for Correspondence: Cumali KARATOPRAK, Bezmialem Vakıf University, Faculty of Medicine,

Cite this article as: Karatoprak C, Akçakaya A, Şentürk H, Çoban G, Şahin N, Türk HM. Report of a Case of Signet Ring Carcinoma Presenting as Gastric Mucosal Thickening: A Diagnostic Dilemma. Bezmialem Science $2021 ; 9(1): 120-4$. 
not be made despite multiple diagnostic methods. In this case, we ought to emphasize that more aggressive decisions should be made if a pathological diagnosis has not been attained despite the use of several different methods.

\section{Case Report}

A 58-year-old female patient was admitted to the outpatient clinic (İstanbul, Turkey) with history of abdominal bloating, constipation, and weight loss $(20 \mathrm{~kg})$ within 2 months. The patient did not have significant health problems until that time. Physical examination did not reveal any abnormality. Moreover, biochemical test and complete blood count results were within the normal range (Table 1). Abdominal sonography was unremarkable. At the first gastroscopy (January 30, 2017), an infiltrative lesion extending from the cardia to the antrum was detected (Figure 1). Multiple forceps biopsies were obtained. However, histology did not reveal malignancy in the first tissue samples taken. Despite these results, gastroscopy and endoscopic US (EUS) were planned due to the doubt of malignancy. In the EUS examination, the stomach wall was significantly thickened up to $13 \mathrm{~mm}$. Physiologic layering of the wall was noted to disappear. Fine-needle aspiration was performed with a $19 \mathrm{G}$ needle from several sites (Figure 2) (February 20, 2017). Histological sections of the second biopsies showed no evidence of lymphoid or other malignancies. There was no infiltrative pathology in the superficial submucosa in endoscopic mucosal resection (EMR) specimens. It was determined to be hypertrophic gastropathy characterized by an increase in inflammatory glands. However, the patient's laboratory (e.g., hypoalbuminemia, hypochlorhydria and eosinophilia) and clinical features (e.g., peripheral edema, anemia) were not characteristic of Menetrier's disease. A definitive diagnosis could not be made despite the second biopsy, and the patient had to be readmitted to the hospital. Contrast-enhanced upper abdominal computed tomography (CT) revealed diffuse thickening in the stomach wall at a thickness of $14 \mathrm{~mm}$. The 18 fluorodeoxyglucose (FDG) positron emission tomography/CT (PET/CT) showed slightly increased FDG uptake (SUVmax, 7) in the cardia, fundus, and corpus regions of the stomach. No other hypermetabolic lesion was observed in any other site (Figure 3). The tumor markers such as AFP (1.93 ng/mL), CEA (0.90 ng/mL), and CA 19-9 $(2.45 \mathrm{U} / \mathrm{mL})$ were found to be within normal ranges. It was concluded that deeper biopsies should be carried out with EUS in the area with gastric mucosal thickening.

The patient underwent gastroscopy and EUS (03.20.2017) for the third time, and a 9-mm irregular thickening on the stomach wall was detected and smear and cell block were prepared by an aspiration with 19-Gauge needle. Histological examination reported no atypical cells in thick-needle biopsies taken for the third time. With the patient's consent, tissue biopsy including all endoscopic layers with the aid of an EUS was decided. The patient was readmitted and a full-layerthickness biopsy was taken from the corpus of the stomach with duodenal endoscopic examination for the fourth time (May 8, 2017). The pathology revealed mucous epithelium in the superficial focal region, few glandular structures in the lamina propria, dense polymorphonuclear leukocytes among fibrin in a large area, and presence of inflammatory cells within the irregular muscle tissue and highlighted the absence of tumor cells (Figure 4). Re-evaluation of the specimens by two different pathologists did not change the result. Laparoscopic evaluation was recommended with the joint decision of a general surgeon, pathologist, hematologist, gastroenterologist, and oncologist. The patient was transferred for surgery, and total gastrectomy was performed. Frozen gastric resection material showed tumoral

Table 1. Laboratory results of the patient

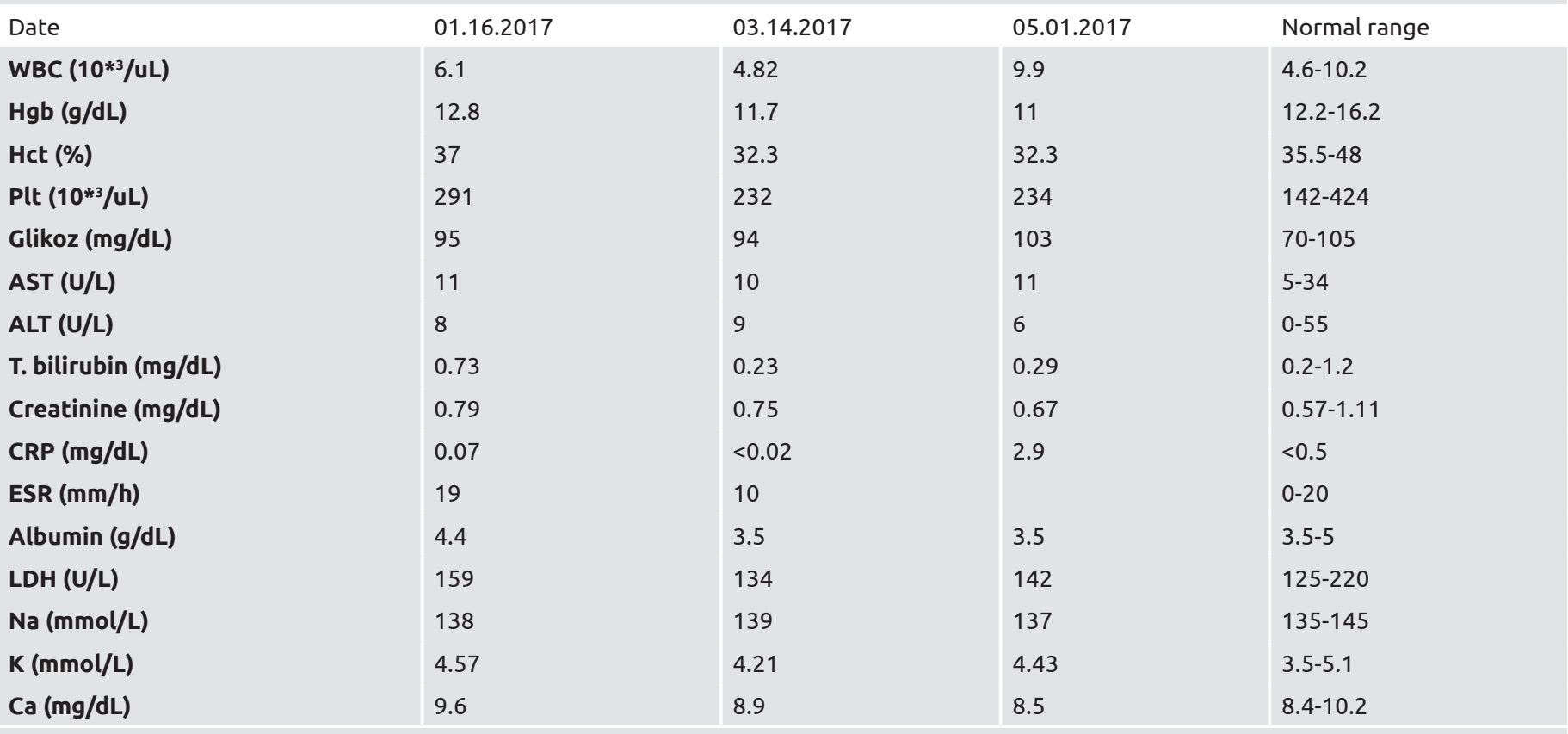

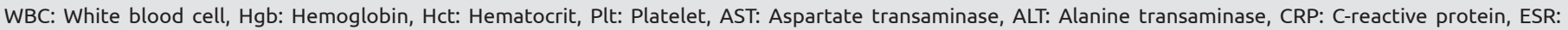
Erythrocyte sedimentation rate, LDH: Lactate dehydrogenase 
cells in signet ring morphology with a diffuse spread pattern and infiltrated appearance up to the serosa. Immunohistochemically, tumor cells were stained positively with pancytokeratin, and the final specimen finding was poorly differentiated signet ring cell adenocarcinoma of the stomach (Figure 5). The patient had an uncomplicated course after surgery and was then scheduled to receive chemotherapy.

\section{Discussion}

There are various difficulties in diagnosing stomach tumors at an early stage. Early diagnosis is difficult because majority of patients are asymptomatic. Sometimes, no laboratory abnormalities are detected in patients with dyspeptic complaints; hence, they are treated symptomatically and further tests are not performed (4). Despite the presence of dyspeptic complaints in our case,
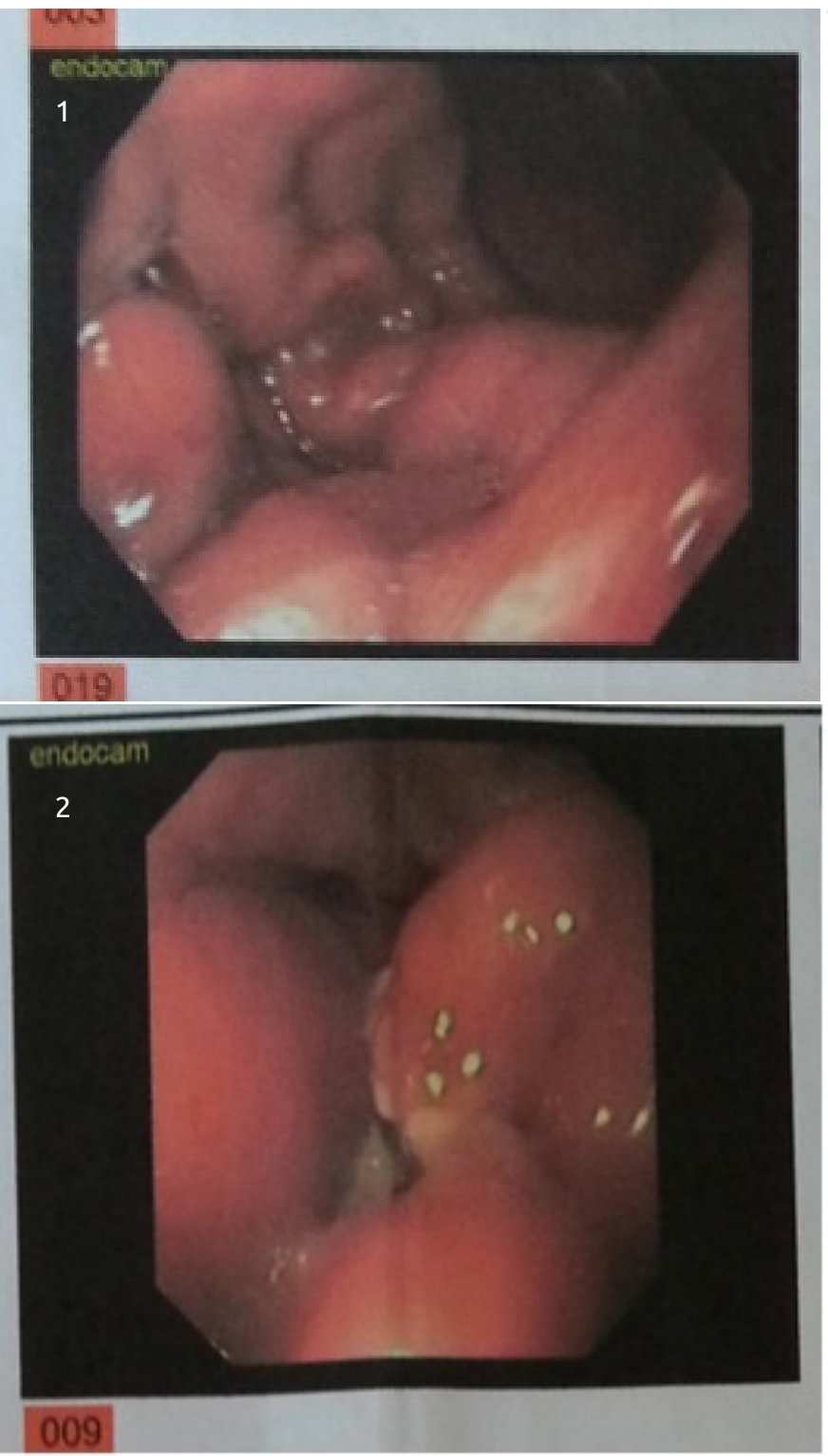

Figure 1-2. First gastroscopic image, second gastroscopic image no pathology was detected in laboratory tests. However, since weight loss was one of the alarm symptoms, further examinations were immediately performed, and gastroscopy was performed to obtain biopsies from multiple lesion sites due to the preliminary differential diagnoses of Menetrier disease, lymphoma, or linitis plastica. Although it is common practice that the histopathological diagnosis is made with the first biopsy in most cases, we could not reach a diagnosis in this case; hence, EMR, multi-deep biopsy, and full-thickness biopsy were performed. The inability to make the diagnosis despite various methods used resulted in delay in taking decisions for prompt treatment in our case. The reason for this is that the treatment of each disease
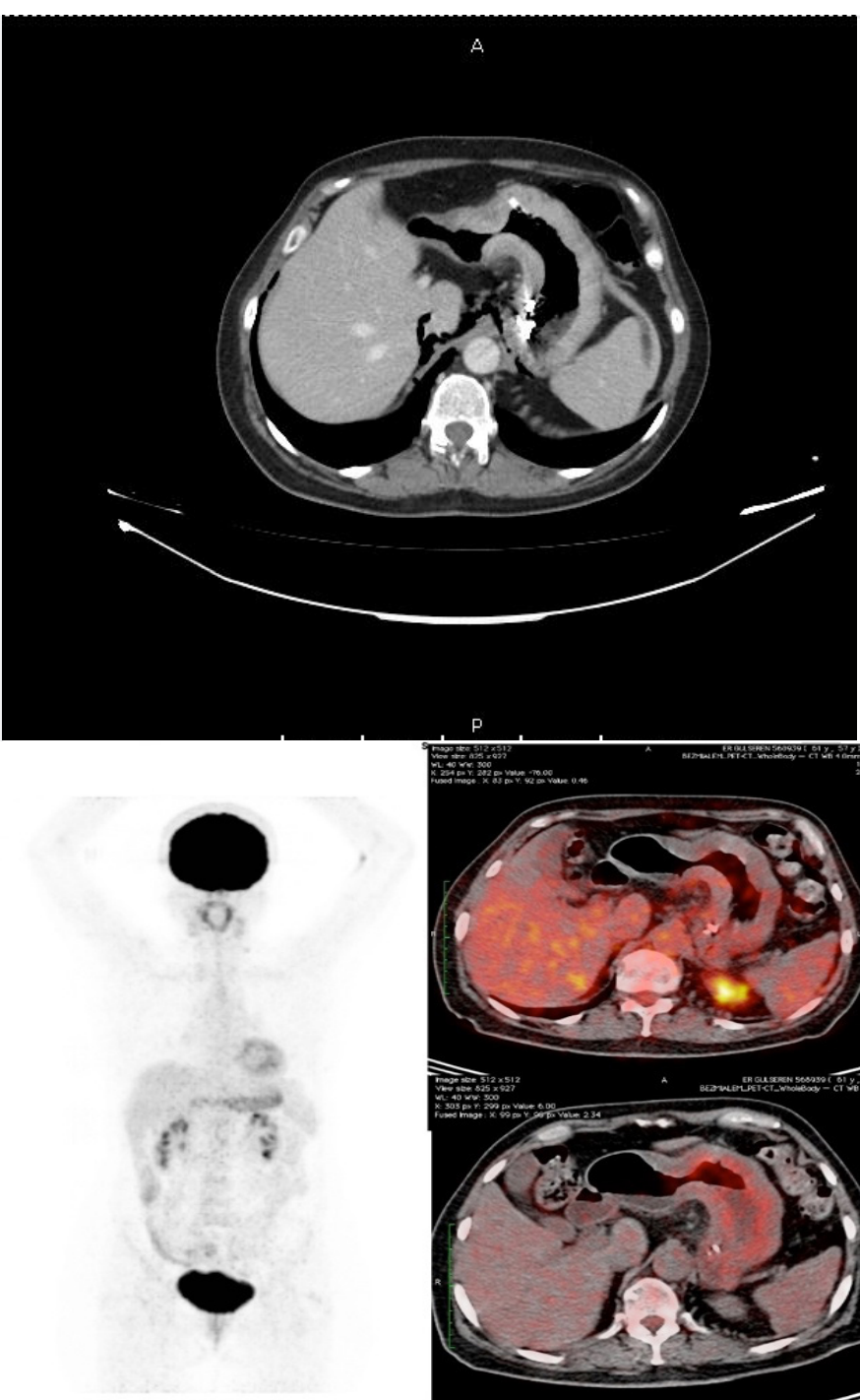

Figure 3. CT and 18 FDG PET/CT images: Contrastenhanced upper abdominal CT revealed diffuse thickening in the stomach wall at a thickness of $14 \mathrm{~mm}$. The 18 FDG PET/CT images of the patient showed diffuse thickening of the stomach wall showing a slightly increased FDG uptake (SUVmax, 7) in the fundus and corpus region of the stomach. No other hypermetabolic lesions were observed in the other regions of the body

CT: Computed tomography, PET/CT: Positron emission tomography/computed tomography, FDG: Fluorodeoxyglucose 

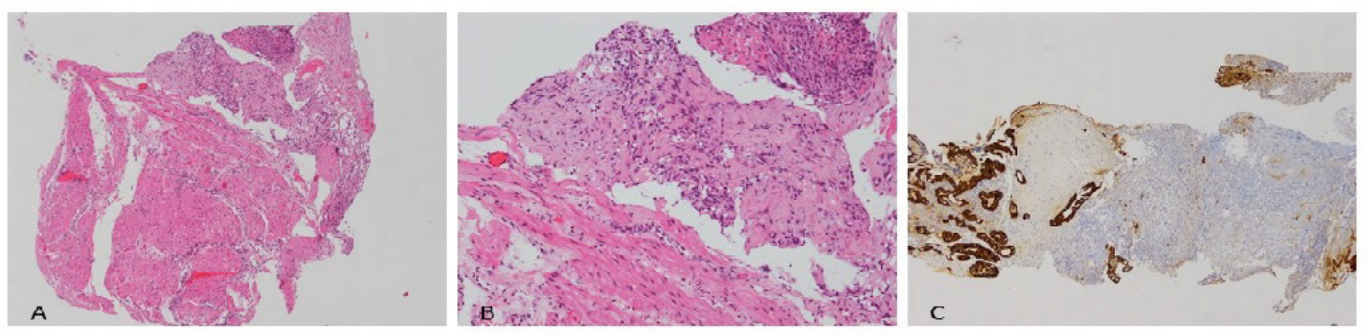

Figure 4. Inflammatory cell infiltration in the fibrin and muscle tissue (A,B-HEx100). Immunohistochemical examination pancreatin staining in surface epithelium and glands (C-HEx100)
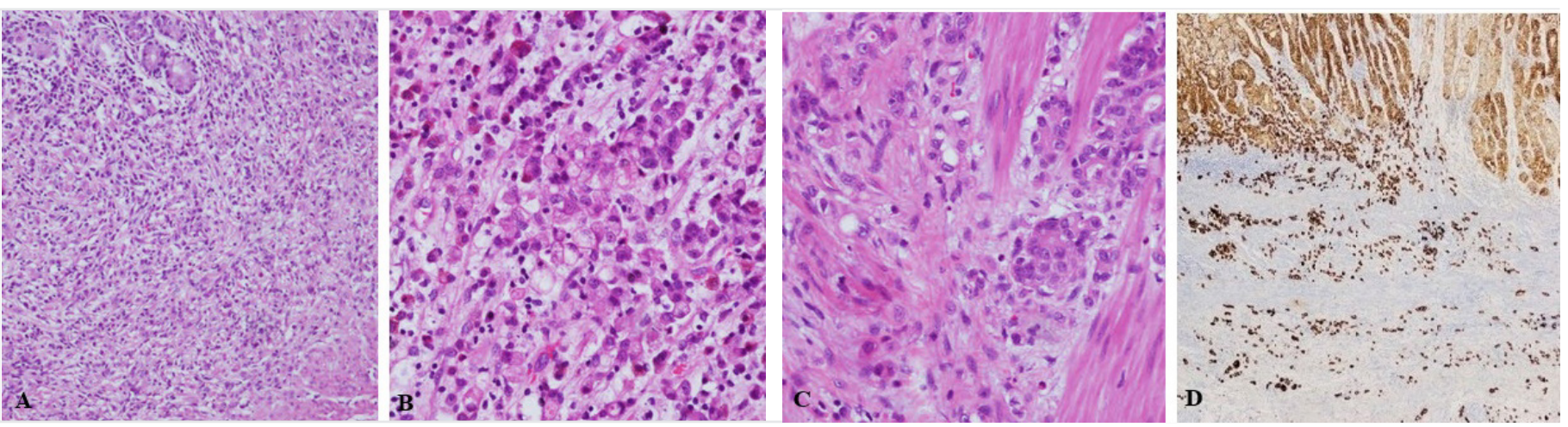

Figure 5. Signet ring cell carcinoma infiltration among inflammatory cells in the mucosa (A-HEx100, B-HEx200). In the muscle tissue, signet ring cells and carcinoma infiltration with glandular appearance (C-HEx200). Positive staining of individual infiltrated tumor cells within the mucosa and submucosa with pancytokeratin (D-HEx100)

differs according to the preliminary diagnosis. If the diagnosis is lymphoma, the treatment should be chemotherapy, radiotherapy, and immunotherapy, whereas the treatment for Menetrier's disease was different $(5,6)$. If linitis plastica is determined as the preliminary diagnosis, surgery should be performed before spread to the lymph nodes and surrounding tissues occurs (7). It is difficult to convince the patients and their relatives to proceed with the operation due to the extensive nature of the surgery and it requiring a wide range of surgical margins and the lack of a pathological diagnosis. Similarly, a pathological diagnosis is warranted before surgery can be done.

Literature on pathologically undiagnosed gastric cancer is scarce. In a meta-analysis, the rate of missed diagnosis of gastric cancer was $10 \%$. It was observed that the majority of patients with missed diagnosis were women under 55 years of age and the final diagnosis was adenocarcinoma. Our patient's case was consistent with that of this group and is compatible with this study (8). In a study from England, endoscopy results of those diagnosed with gastric cancer within 3 years before the diagnosis were screened, and it was found that in $8.3 \%$ of the patients, the diagnosis of gastric cancer was missed at endoscopy, and the most common diagnosis at a previous endoscopy was benign gastric ulcer (9). Despite this awareness of cancer, in our case, four different modalities of endoscopy were performed; however, a definitive diagnosis could not be reached. Our case is significant as to our knowledge, there is no similar case report in the literature.
These unknowns distress the clinician and the patient. In this case, although we were a reference hospital and endoscopy center, we could not attain a definitive diagnosis. We considered the lack of a guide in such challenging situations as a limitation.

In conclusion, there may be cases in which the diagnosis cannot be reached despite the use of advanced technology and experienced doctors. Intermittent follow-up in these cases may cause treatment delay and lead to cancer progression. Therefore, we suggest that more invasive interventions should be performed in cases wherein malignancy is suspected (especially in the presence of alarm symptoms/signs) and the diagnosis cannot be obtained with the usual diagnostic modalities.

Informed Consent: With the patient's consent, tissue biopsy including all endoscopic layers with the aid of an EUS was decided.

Peer-review: Internally and externally peer reviewed.

\section{Authorship Contributions}

Surgical and Medical Practices: A.A., H.Ş., Concept: C.K., Design: C.K., H.M.T., Data Collection or Processing: G.Ç., N.Ş., Analysis or Interpretation: A.A., H.Ş., G.Ç., N.Ş., H.M.T., Literature Search: C.K., H.M.T., Writing: C.K.

Conflict of Interest: No conflict of interest was declared by the authors. 
Financial Disclosure: The authors declared that this study received no financial support.

\section{References}

1. Zhou Y, Abel GA, Hamilton W, Pritchard-Jones K, Gross CP, Walter FM, et al. Diagnosis of cancer as an emergency: a critical review of current evidence. Nat Rev Clin Oncol 2017;14:45-56.

2. Ngamruengphong S, Abe S, Oda I. Endoscopic Management of Early Gastric Adenocarcinoma and Preinvasive Gastric Lesions. Surg Clin North Am 2017;97:371-85.

3. Marin-Gabriel JC, Martos-Vizcaino E, Diaz-Tasende J, AlonsoRiano M, Perez-Carreras M, Rodriguez-Munoz S, et al. Endoscopic submucosal dissection (ESD) of antral subepithelial lesion suspected of malignancy. Rev Esp Enferm Dig 2015;107:380-3.

4. Hudler P. Challenges of deciphering gastric cancer heterogeneity. World J Gastroenterol 2015;21:10510-27.
5. Ikoma N, Badgwell BD, Mansfield PF. Multimodality Treatment of Gastric Lymphoma. Surg Clin North Am 2017;97:405-20.

6. Burdick JS, Chung E, Tanner G, Sun M, Paciga JE, Cheng JQ, et al. Treatment of Menetrier's disease with a monoclonal antibody against the epidermal growth factor receptor. N Engl J Med 2000;343:1697701.

7. Agnes A, Estrella JS, Badgwell B. The significance of a nineteenth century definition in the era of genomics: linitis plastica. World J Surg Oncol 2017;15:123.

8. Pimenta-Melo AR, Monteiro-Soares M, Libanio D, Dinis-Ribeiro M. Missing rate for gastric cancer during upper gastrointestinal endoscopy: a systematic review and meta-analysis. Eur J Gastroenterol Hepatol 2016;28:1041-9.

9. Chadwick G, Groene O, Riley S, Hardwick R, Crosby T, Hoare J, et al. Gastric Cancers Missed During Endoscopy in England. Clin Gastroenterol Hepatol 2015;13:1264-70e1. 